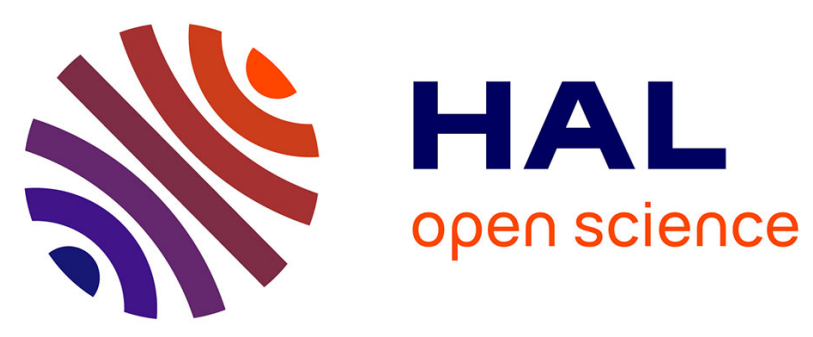

\title{
Reductive dehalogenation of a chloroacetanilide herbicide in a flow electrochemical cell fitted with Ag-modified Ni foams
}

Wenyan He, Yaoyin Lou, Enrico Verlato, Isabelle Soutrel, Didier Floner, Florence Fourcade, Abdeltif Amrane, Marco Musiani, Florence Geneste

\section{To cite this version:}

Wenyan He, Yaoyin Lou, Enrico Verlato, Isabelle Soutrel, Didier Floner, et al.. Reductive dehalogenation of a chloroacetanilide herbicide in a flow electrochemical cell fitted with Ag-modified Ni foams. Journal of Chemical Technology and Biotechnology, 2018, 93 (6), pp.1572-1578. 10.1002/jctb.5523 . hal-01807078

HAL Id: hal-01807078

https://hal-univ-rennes1.archives-ouvertes.fr/hal-01807078

Submitted on 14 Jun 2018

HAL is a multi-disciplinary open access archive for the deposit and dissemination of scientific research documents, whether they are published or not. The documents may come from teaching and research institutions in France or abroad, or from public or private research centers.
L'archive ouverte pluridisciplinaire HAL, est destinée au dépôt et à la diffusion de documents scientifiques de niveau recherche, publiés ou non, émanant des établissements d'enseignement et de recherche français ou étrangers, des laboratoires publics ou privés. 


\title{
Reductive dehalogenation of a chloroacetanilide herbicide in a flow electrochemical cell fitted with Ag-modified Ni foams
}

Wenyan $\mathrm{He}^{\mathrm{a}, \mathrm{b}}$, Yaoyin Lou $^{\mathrm{a}, \mathrm{b}}$, Enrico Verlato ${ }^{\mathrm{c}}$, Isabelle Soutrel ${ }^{\mathrm{a}}$, Didier Floner ${ }^{\mathrm{b}}$, Florence Fourcade $^{\mathrm{a}}$, Abdeltif Amrane ${ }^{\mathrm{a}}$, Marco Musiani ${ }^{*}$,, Florence Geneste ${ }^{*}$, b

${ }^{a}$ Ecole Nationale Supérieure de Chimie de Rennes/Université de Rennes 1, CNRS, UMR 6226, 11 allée de Beaulieu, CS 50837, 35708 Rennes cedex 7, France.

${ }^{b}$ Université de Rennes 1, CNRS, UMR 6226, Equipe Matière Condensée et Systèmes Electroactifs, Campus de Beaulieu, 35042 Rennes cedex, France.

${ }^{c}$ ICMATE CNR - Corso Stati Uniti 4 - 35124 Padova Italy

\begin{abstract}
BACKGROUND: The aim of this work is to adapt the electrochemical reduction of Alachlor $^{\mathrm{TM}}$, using Ag-modified $\mathrm{Ni}$ foam electrodes to environmental applications. In this context, preparative electrolyses of Alachlor ${ }^{\mathrm{TM}}$ were performed in a flow electrochemical cell in different electrolytic media.
\end{abstract}

RESULTS: The highest catalytic activity towards the reduction of Alachlor ${ }^{\mathrm{TM}}$ was obtained in $0.05 \mathrm{~mol} \mathrm{~L}^{-1} \mathrm{NaOH}$, with a conversion yield of $93 \%$. The dechlorination yield of Alachlor ${ }^{\mathrm{TM}}$ estimated from the $\mathrm{Cl}^{-}$concentration was $77 \%$, significantly lower than its conversion yield, but higher than the yield of deschloroalachlor (69\%), the main dehalogenated by-product, indicating the presence of other by-products.

CONCLUSIONS: A total reduction of Alachlor ${ }^{\mathrm{TM}}$ was achieved in conditions adapted to environmental applications, showing that this process can be used for dechlorination treatment of Alachlor ${ }^{\mathrm{TM}}$ in aqueous media. Although a high dechlorination yield was

Corresponding authors. E-mail address: Florence.Geneste@univ-rennes1.fr (Florence Geneste)

E-mail address: m.musiani@ieni.cnr.it (Marco Musiani) 
obtained, biodegradability estimated from $\mathrm{BOD}_{5}$ measurements remained low, showing that the $\mathrm{C}-\mathrm{Cl}$ bond is not the only functional group that is responsible for the biorecalcitrance of Alachlor ${ }^{\mathrm{TM}}$.

\section{INTRODUCTION}

Chloroacetanilide herbicides are a relatively old class of herbicides used to control the growth of weeds in corn, cotton, peanuts, dry beans/peas, sunflower, soybeans and several other crops. In this class of herbicides, Alachlor ${ }^{\mathrm{TM}}$, Acetochlor ${ }^{\mathrm{TM}}$, Metolachlor ${ }^{\mathrm{TM}}$ and Propachlor ${ }^{\mathrm{TM}}$ are the most used compounds in commercial formulations. Due to their extensive usage and to their solubility in water they have been frequently detected in soil and surface and ground waters. $^{1-6}$ This is particularly worrying since chloroacetanilides toxicity has already been reported $^{7,8}$ as well as their probable carcinogenicity. ${ }^{9,10}$

Since chloroacetanilide herbicides are persistent and not readily biodegradable, their degradation by physico-chemical processes has been widely investigated ${ }^{11-19}$. Among them, the reductive dechlorination of chloroacetanilide herbicides seems to be particularly relevant since it is a selective and well-controlled process and it is likely to increase their

biodegradability since chloro-groups are often responsible of the biorecalcitrance of substrates. $^{20}$

Most of the chlorinated molecules can be directly reduced on cathodes but at very cathodic potentials close to the reduction of water. ${ }^{21,22}$ This results in hydrogen evolution, preventing sometimes an efficient reduction of the compound. Therefore, electrodes with catalytic properties allowing the reductive dechlorination at less cathodic potentials are required. The electrocatalytic reduction of the $\mathrm{C}-\mathrm{Cl}$ bond can be achieved on electrodes modified with organometallic catalysts or with metals. ${ }^{18,23-25}$ Among the different metals that have been studied, silver has been the subject of many investigations since it presents a high 
electrocatalytic activity towards the reduction of carbon-chlorine bonds. This property has been attributed to its high electrophilicity due to specific interactions of the $\mathrm{C}-\mathrm{Cl}$ bond with silver that lowers the driving force of the electron transfer. ${ }^{26}$ Many studies deal with aqueous medium to achieve degradation of environmental pollutants such as chlorinated solvents and pesticides. $^{27-31}$ Thus, silver cathodes have shown good catalytic activity towards the dechlorination of solvents such as polychloromethanes, polychloroethanes, and polychloroethylenes. ${ }^{28,29,32,33}$ Total and partial dechlorinations of polychlorophenols and other aromatic species by reduction on silver electrode have also been reported. ${ }^{27}, 34-36$ Bimetallic and trimetallic electrodes such as $\mathrm{Ag} / \mathrm{Pd}, \mathrm{Ag} / \mathrm{Fe}, \mathrm{Ag} / \mathrm{Mg}$ and $\mathrm{Pd} / \mathrm{Ag} / \mathrm{Ni}$ have proven their efficiency for the electrocatalytic reduction of chlorinated compounds. ${ }^{37-47}$ More recently, the attention has been focused on nanostructured particles of silver due to their large surface-to-volume ratio that is critical for mass transfer and to the achievement of efficient composite materials with low precious metal loading. ${ }^{48-50}$

We recently reported an original method to prepare Ni foams modified with Ag nanoparticles by galvanic displacement and their use for reductive dechlorination of chloroacetanilide herbicides. $^{51}$ To go further into the environmental application and test the possibility to achieve a combined process involving an electrochemical pre-treatment followed by a biological process, we used Ag-modified $\mathrm{Ni}$ foams ${ }^{51}$ in a flow electrochemical cell in different electrolytic media for dechlorination of Alachlor ${ }^{\mathrm{TM}}$. We will see that these new electrolytic conditions easily adaptable to large-scale process allow a quasi-total dechlorination of Alachlor ${ }^{\mathrm{TM}}$. The biodegradability of the solution after electrolysis was evaluated and by-products analysis was performed.

\section{MATERIALS AND METHODS}

\section{Chemicals and materials}


Alachlor ${ }^{\mathrm{TM}}$ (2-chloro- $N$-(2,6-diethylphenyl)- $N$-(methoxymethyl)acetamide) and Lithium perchlorate were purchased from Sigma-Aldrich. Deschloroalachlor ( $N$-(2,6-diethylphenyl)$N$-(methoxymethyl)acetamide) was obtained from Alpha Chimica (France). 2-chloro-N-(2,6diethylphenyl) acetamide was got from Fluorochem Limited. Sodium thiosulfate pentahydrate $\left(\mathrm{Na}_{2} \mathrm{~S}_{2} \mathrm{O}_{3} \cdot 5 \mathrm{H}_{2} \mathrm{O}\right)$, silver nitrate $\left(\mathrm{AgNO}_{3}\right)$, PVP (polyvinylpyrrolidone, M.W. 10,000) were purchased from Alfa Aesar. The Ni 3D substrates used for the preparation of Ag-modified Ni foam electrodes (henceforth called $\mathrm{Ag}-\mathrm{Ni}$ ) were $0.17 \mathrm{~cm}$ thick INCOFOAM ${ }^{\mathrm{TM}}$ sheets, with 50 pores per linear inch, apparent density $0.22 \mathrm{~g} \mathrm{~cm}^{-3}$ and void volume fraction 0.975 .

\section{Preparation of Ag-Ni foam electrodes}

The deposition of $\mathrm{Ag}$ nanoparticles on $\mathrm{Ni}$ foam was described in literature ${ }^{51}$. Before its use in spontaneous deposition or in electrolysis experiments, the Ni foam was successively washed with acetone, dichloromethane, dried in a nitrogen stream and then washed again with water or $0.5 \mathrm{M} \mathrm{HNO}_{3}$ in an ultrasonic bath. $\mathrm{Ag}$ deposition was performed by immersing the $\mathrm{Ni}$ foams in a mixture solution of $10 \times 10^{-3} \mathrm{~mol} \mathrm{~L}^{-1} \mathrm{AgNO}_{3}$ and $80 \times 10^{-3} \mathrm{~mol} \mathrm{~L}^{-1} \mathrm{Na}_{2} \mathrm{~S}_{2} \mathrm{O}_{3}$ in the presence or absence of $0.2 \times 10^{-3} \mathrm{~mol} \mathrm{~L}^{-1}$ polyvinylpyrrolidone (PVP), a capping agent used to control the shape and size of Ag nanoparticles ${ }^{52-54}$, at open circuit, and by leaving the $\mathrm{Ni} / \mathrm{Ag}$ galvanic displacement reaction under nitrogen to proceed for $15 \mathrm{~min}$. The deposition temperature was kept at $25{ }^{\circ} \mathrm{C}$ with a thermostat.

\section{Dechlorination conditions}

The dechlorination reaction was performed in a home-made flow cell. ${ }^{25}$ The Ni foam or Agmodified Ni foam electrode (10 $\mathrm{mm}$ diameter and $1.7 \mathrm{~mm}$ width) was located between two interconnected DSA counter-electrodes (dimensionally stable anodes, AC-2004, supplied by ECS International Electro Chemical Services, France) to improve the homogeneity of the potential distribution in the three dimensional working electrode. The compartments were separated by cationic exchange membranes (Ionac 3470 - Lanxess SAS, Courbevoie, France). 
The reference electrode (Mercury-saturated mercurous sulfate - MSE) was positioned in the middle of the working electrode and a potential of -1.6 V/MSE was applied using a VersaSTAT 3 potentiostat from Ametek/Princeton Applied (Elancourt, France). $25 \mathrm{~mL}$ of the solution $\left(50 \mathrm{mg} \mathrm{L}^{-1}\right.$ pesticide in $0.1 \mathrm{~mol} \mathrm{~L}^{-1} \mathrm{LiClO}_{4}$ or $\left.0.05 \mathrm{~mol} \mathrm{~L}^{-1} \mathrm{NaOH}\right)$ percolated the porous electrode at different flow rates ranging from 1 to $3 \mathrm{~mL} \mathrm{~min}^{-1}$ monitored by a Gilson minipuls 3 peristaltic pump (Middleton, WI, USA).

\section{Analytical procedures}

Ultra-pressure liquid chromatography-MS/MS analysis conditions have been previously reported. ${ }^{18}$

\section{Total Organic Carbon (TOC) measurements}

TOC was measured by means of a TOC-V $\mathrm{CPH} / \mathrm{CPN}$ Total Organic Analyzer Schimadzu. The solutions were filtered on Sartorius Stedim Minisart $0.45 \mu \mathrm{m}$ GF prefilters (Goettingen, Germany) before each analysis and then diluted ten times with ultrapure water. Organic carbon compounds were combusted and converted to $\mathrm{CO}_{2}$. The amount of produced $\mathrm{CO}_{2}$ was measured by a non-dispersive infrared detector (NDIR). The standard NPOC (Non-Purgeable Organic Carbon) method was used to obtain reproducible TOC values. For each sample, each measurement was triplicated.

\section{Chemical Oxygen Demand (COD) measurements}

COD was measured with a Test Nanocolor ${ }^{\circledR}$ CSB 160 from Macherey-Nagel (Düren, Germany). The amount of oxygen required for the oxidation of the sample with $\mathrm{K}_{2} \mathrm{Cr}_{2} \mathrm{O}_{7}$ at acidic $\mathrm{pH}$ at $148^{\circ} \mathrm{C}$ for $2 \mathrm{~h}$ was quantified.

\section{Biological Oxygen Demand (BOD5) measurements}


The samples were neutralized using a solution of sulfuric acid before the analysis. $\mathrm{BOD}_{5}$ measurement was carried out with the Nanocolor ${ }^{\circledR}$ BOD5 test, allowing a simple determination of the biological oxygen demand of a diluted sample. The oxygen-enriched sample was incubated in test tubes for 5 days at $20 \pm 1{ }^{\circ} \mathrm{C}$ in the dark. The quantification of dissolved oxygen was performed after five days using the method of Winkler EN25813-G21 by photometric evaluation of the iodine color.

\section{Ion chromatography}

The concentration of chloride ions (diluted four times and two times for electrolyses performed in $\mathrm{LiClO}_{4}$ and $\mathrm{NaOH}$, respectively) before and after electrolysis was determined using DIONEX DX120 ion chromatography equipped with a conductivity detector and a DIONEX AS19 $(4 \times 250 \mathrm{~mm})$ ion-exclusion column. The sample was eluted with potassium

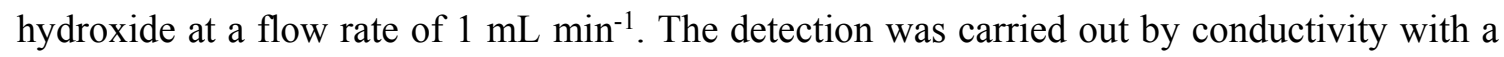
Self Regenerating Suppressor (SRS).

\section{RESULTS AND DISCUSSION}

\section{Optimization of the electrolytic conditions}

The activity of Ag-modified Ni foams for the dechlorination of Alachlor ${ }^{\mathrm{TM}}$ (Scheme 1) in a two-compartment cell has been shown in our previous study. ${ }^{51}$

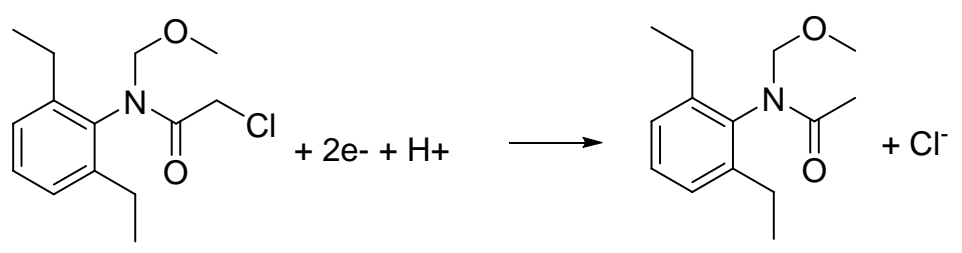

Scheme 1: dechlorination of Alachlor ${ }^{\mathrm{TM}}$ into descholoroalachlor

Different experimental conditions were used to prepare these electrodes: (i) Ag-Ni, the foam 
electrodes prepared by depositing Ag onto Ni cleaned with organic solvents, (ii) etched Ag-Ni, those prepared by deposition onto $\mathrm{Ni}$ foams treated with $0.5 \mathrm{~mol} \mathrm{~L}^{-1} \mathrm{HNO}_{3}$ in ultrasonic bath to eliminate surface oxides and promote the galvanic exchange with silver, and (iii) etched Ag-PVP-Ni, those prepared in the presence of PVP to control the shape and size of the Ag particles. In the present study, these electrodes were used in a flow electrochemical cell, with solution recycling, to improve mass transport and to be close to environmental applications. First attempts were performed in a flow cell for electrochemical dechlorination of $1.8 \times 10^{-4}$ mol L-1 $(50 \mathrm{ppm})$ alachlor ${ }^{\mathrm{TM}}$ in $0.1 \mathrm{~mol} \mathrm{~L}^{-1} \mathrm{LiClO}_{4}$ at $-1.6 \mathrm{~V} / \mathrm{MSE}$ for $2 \mathrm{~h}$ at a flow rate of 1 $\mathrm{mL} \min ^{-1}$. Electrolyte concentration was increased compared with previous experiments performed in a separated cell $\left(0.05 \mathrm{~mol} \mathrm{~L}^{-1} \mathrm{LiClO}_{4}\right)^{51}$ to improve the conductivity of the solution. The potential value of $-1.6 \mathrm{~V} / \mathrm{MSE}$ for the electrolysis has been previously optimized. ${ }^{51}$ The concentration of Alachlor ${ }^{\mathrm{TM}}$ during the electrolysis was analyzed by UPLC. Table 1 shows that all Ag-modified Ni foam electrodes gave markedly higher conversion yields of Alachlor ${ }^{\mathrm{TM}}$ (from $44 \%$ to $86 \%$ ) than unmodified $\mathrm{Ni}$ foam $(26 \%)$, underlining the catalytic activity of silver nanoparticles. The order of reactivity was similar to previous experiments. ${ }^{51}$ The etched Ag modified Ni foam had a higher rate than non-etching foams, as shown in Fig.1. With the etched Ni-PVP-Ag electrode, a faster reduction of Alachlor ${ }^{\mathrm{TM}}$ was obtained with a conversion of $86 \%$ when the electrolysis time was increased to $4 \mathrm{~h}$ at a flow rate of $2 \mathrm{~mL} \mathrm{~min} \mathrm{~m}^{-1}$, namely $19 \%$ higher than for $2 \mathrm{~h}$ at $1 \mathrm{~mL} \mathrm{~min}$. Thus higher electrolysis time and flow rates allow a better recycling of the solution through the porous electrode improving the conversion of Alachlor ${ }^{\mathrm{TM}}$. This result was quite close to the best one $(92 \%)$ previously obtained in a separated cell after $5 \mathrm{~h}$ of electrolysis and could be attributed to a higher surface area of silver on the electrode surface. ${ }^{51}$ The current efficiency was low $(1.7 \%$ $3.8 \%$ ) with all kinds of electrodes owing to the competition with hydrogen evolution. ${ }^{51} \mathrm{~A}$ better selectivity could be obtained at potentials less negative than $-1.6 \mathrm{~V}$, but with 
significantly lower current. Although it does not optimize the current efficiency, the chosen potential represents a good compromise.

Table 1. Conversions of Alachlor ${ }^{\mathrm{TM}}$ solutions after reductive dechlorination at $-1.6 \mathrm{~V} / \mathrm{MSE}$ performed in $0.1 \mathrm{~mol} \mathrm{~L}^{-1} \mathrm{LiClO}_{4}$ solution containing $50 \mathrm{ppm}^{\text {Alachlor }}{ }^{\mathrm{TM}}$ in a flow electrochemical cell with Ag-modified $\mathrm{Ni}$ foams (volume: $0.1335 \mathrm{~cm}^{3}$ ).

\begin{tabular}{lllll}
\hline Electrode & Time $/ \mathrm{h}$ & Flow rate $/ \mathrm{mL} \mathrm{min}^{-1}$ & Conversion $/ \%$ & Current efficiency / \% \\
\hline Ni foam & 2 & 1 & 26 & - \\
Ag-Ni & 2 & 1 & 44 & 1.7 \\
Etched Ag-Ni & 2 & 1 & 58 & 2.7 \\
Etched & 2 & 1 & 67 & 3.8 \\
Ag-PVP-Ni & & & & \\
Etched & 4 & 2 & 86 & 2.2 \\
Ag-PVP-Ni & & & & \\
\hline
\end{tabular}

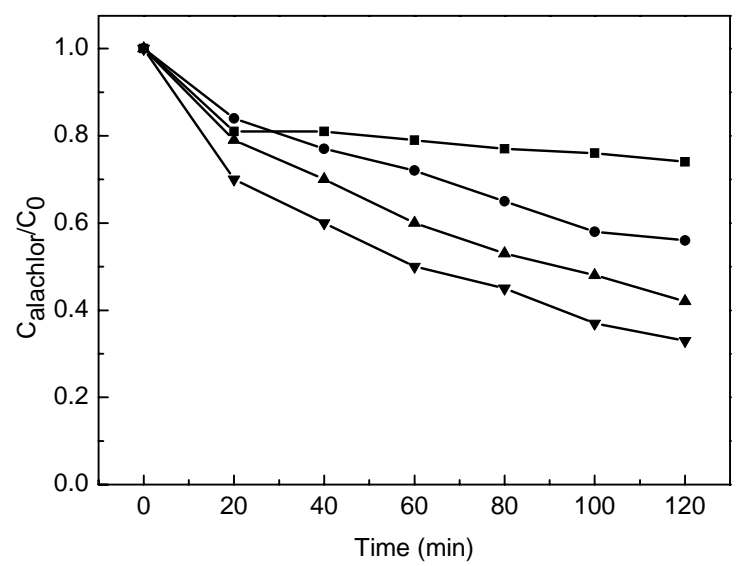

Figure 1. Evolution of the normalized concentration $\mathrm{C}_{\text {alachlor }} / \mathrm{C}_{0}$ vs electrolysis time for cathodic reduction of Alachlor ${ }^{\mathrm{TM}}\left(1.8 \times 10^{-4} \mathrm{~mol} \mathrm{~L}^{-1} ; 50 \mathrm{ppm}\right)$ performed at $-1.6 \mathrm{~V} / \mathrm{MSE}$ in $0.1 \mathrm{~mol} \mathrm{~L}^{-1} \mathrm{LiClO}_{4}$ with $\mathrm{Ni}$ foam $(\boldsymbol{\bullet}), \mathrm{Ag}-\mathrm{Ni}(\bullet)$, etched Ag-Ni ( $\left.\boldsymbol{\Delta}\right)$ and etched Ag-PVP-Ni $(\boldsymbol{\nabla})$ at $1 \mathrm{~mL} \mathrm{~min}^{-1}$.

To check if a process combining the electroreduction and a biological treatment was possible, the biodegradability of the electrolyzed solution was tested. However, $\mathrm{BOD}_{5}$ measurement of the electrolyte alone $\left(0.1 \mathrm{~mol} \mathrm{~L}^{-1} \mathrm{LiClO}_{4}\right)$ highlighted the toxicity of the solution for activated sludge. The electrolyses were then performed in sodium hydroxide solutions (Table 2), which have good conductivity, are compatible with the nickel support and could be adjusted to 
neutral $\mathrm{pH}$ before testing the biodegradability of the electrolyzed solution. Thus, the cathodic reduction of Alachlor ${ }^{\mathrm{TM}}\left(50 \mathrm{ppm} ; 1.8 \times 10^{-4} \mathrm{~mol} \mathrm{~L}^{-1}\right)$ was carried out in $0.05 \mathrm{~mol} \mathrm{~L}^{-1} \mathrm{NaOH}$ at -1.6 V/MSE on etched Ni-PVP-Ag, leading to $89 \%$ conversion yield of Alachlor ${ }^{\mathrm{TM}}$ after $4 \mathrm{~h}$ and $93 \%$ after $5 \mathrm{~h}$. For comparison, all Ag-modified Ni foams were tested under the same conditions. Their catalytic activity followed the same order than in $0.1 \mathrm{~mol} \mathrm{~L}^{-1} \mathrm{LiClO}_{4}:^{51} \mathrm{Ni}$ $\mathrm{Ag}<$ Etched Ni-Ag $<$ Etched Ni-PVP-Ag. It is worthy to note that the conversion yield of Alachlor ${ }^{\mathrm{TM}}$ was higher on etched $\mathrm{Ni}$ foam than on $\mathrm{Ni}$ foam. This result can be explained by an increase of the surface area after etching and by a good control of the shape and the size of silver nanoparticles during their formation in the presence of PVP, leading to a higher silver nanoparticles density. ${ }^{51}$ However, the comparison of the conversion of Alachlor ${ }^{\mathrm{TM}}$ on Nifoams with Ag-modified Ni foams highlighted the catalytic activity of silver nanoparticles even if the Ni foam was etched (Fig. 2a,b). The current efficiency was low with a range between 1.8 and $2.7 \%$, due to the competition with hydrogen evolution.

Table 2. Conversions of Alachlor ${ }^{\mathrm{TM}}$ solutions after reductive dechlorination at $-1.6 \mathrm{~V} / \mathrm{MSE}$ performed in $0.05 \mathrm{M} \mathrm{NaOH}$ containing 50 ppm Alachlor $^{\mathrm{TM}}$ in a flow electrochemical cell (Flow rate $3 \mathrm{~mL} \mathrm{~min}^{-1}$ ) with Ag-modified Ni foams (volume: $0.1335 \mathrm{~cm}^{3}$ ) for $5 \mathrm{~h}$.

\begin{tabular}{llc}
\hline Electrode & Conversion ${ }^{\mathrm{a}} / \%$ & Current efficiency / \% \\
\hline Ni foam & $36 \pm 1$ & 1.8 \\
& & \\
Etched Ni foam & $65 \pm 2$ & 1.8 \\
Ag-Ni & $74 \pm 2$ & 1.8 \\
Etched Ag-Ni & $85 \pm 1$ & 2.4 \\
Etched Ag-PVP-Ni & $93 \pm 3$ & 2.7 \\
\hline
\end{tabular}

${ }^{\mathrm{a}}$ Uncertainties are based on two dechlorination experiments 

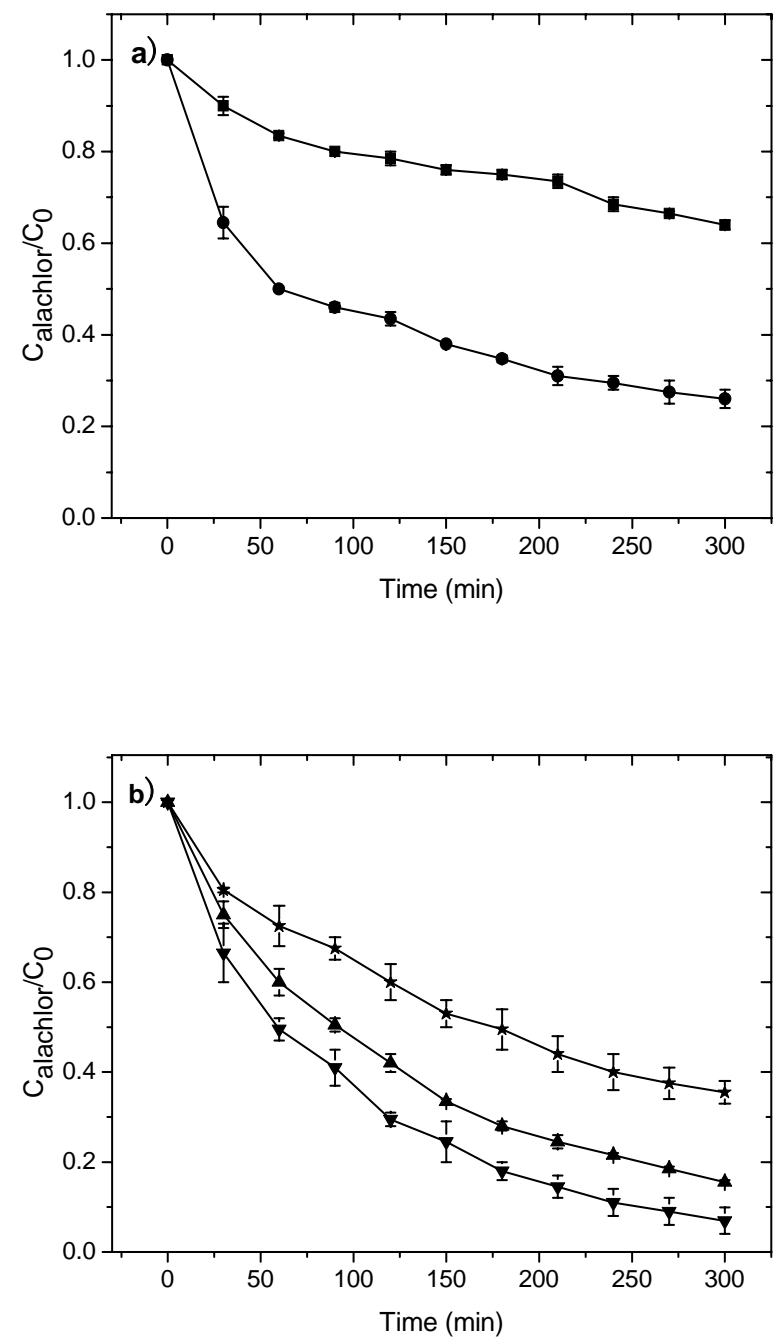

Figure 2. Evolution of the normalized concentration $\mathrm{C}_{\text {alachlor }} / \mathrm{C}_{0}$ vs electrolysis time for cathodic reduction of Alachlor ${ }^{\mathrm{TM}}\left(1.8 \times 10^{-4} \mathrm{~mol} \mathrm{~L}^{-1} ; 50 \mathrm{ppm}\right)$ performed at $-1.6 \mathrm{~V} / \mathrm{MSE}$ in 0.05 mol L-1 $\mathrm{NaOH}$ with : a) $\mathrm{Ni}$ foam $(\boldsymbol{\bullet}), \operatorname{Ag}-\mathrm{Ni}(\bullet)$; b) etched $\mathrm{Ni}$ foam $(\star)$, etched $\mathrm{Ag}-\mathrm{Ni}$ $(\boldsymbol{\Delta})$, etched Ag-PVP-Ni $(\boldsymbol{\nabla})$ at $3 \mathrm{~mL} \mathrm{~min}^{-1}$. Error bars are based on two reproducibility measurements.

The stability of the Ag-modified electrodes after electrolysis was checked by SEM (Fig. 3). 

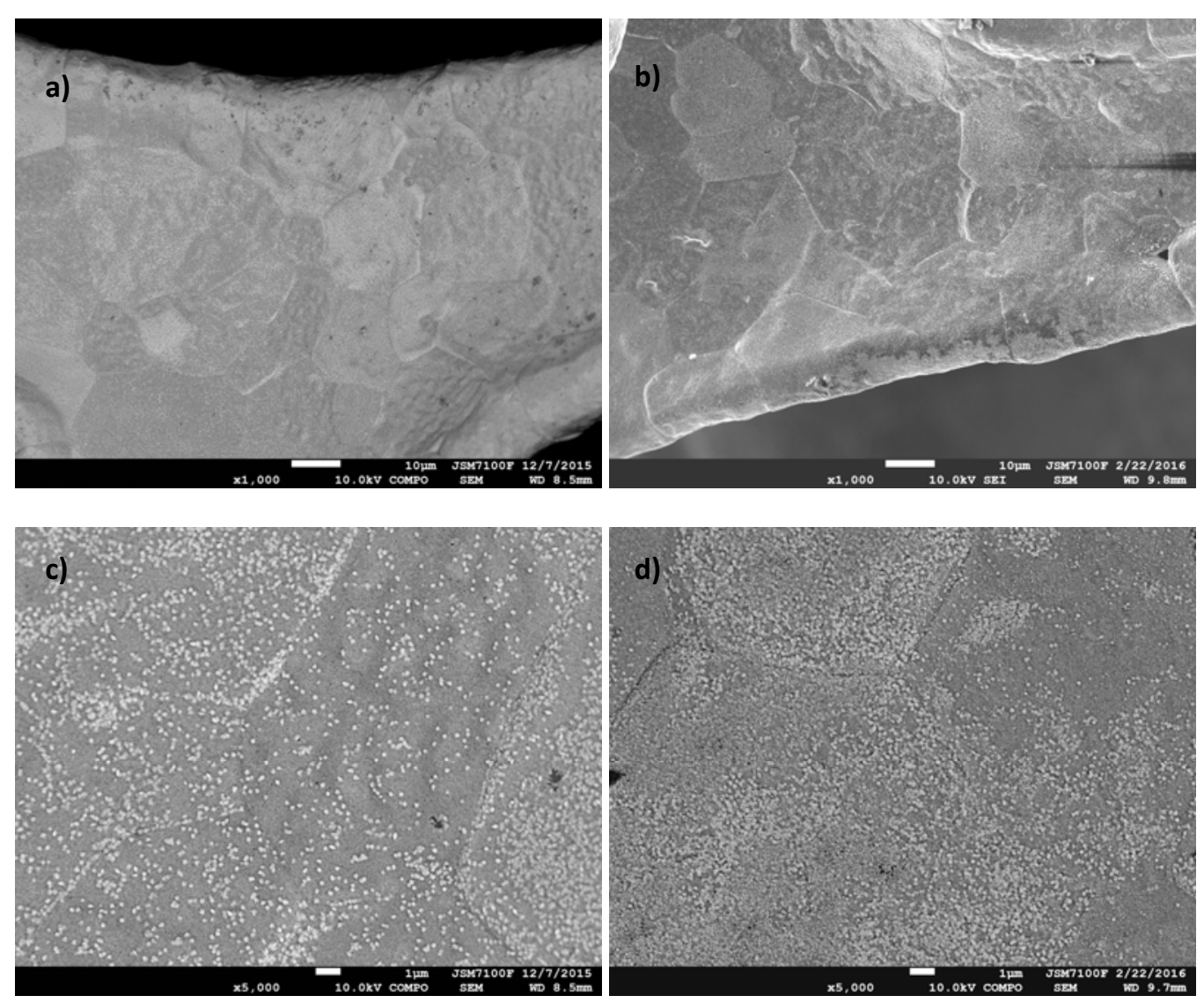

Figure 3. SEM images of etched Ag-PVP-Ni electrodes before $(\mathrm{a} \times 1000, \mathrm{c} \times 5000)$ and after $(\mathrm{b} \times 1000, \mathrm{~d} \times 5000)$ cathodic reduction of Alachlor ${ }^{\mathrm{TM}}\left(1.8 \times 10^{-4} \mathrm{~mol} \mathrm{~L}^{-1} ; 50 \mathrm{ppm}\right)$ performed at $-1.6 \mathrm{~V} / \mathrm{MSE}$ in $0.05 \mathrm{~mol} \mathrm{~L}^{-1} \mathrm{NaOH}$

The presence of silver nanoparticles (white points) was clearly observed on the Ni foam surface. Comparison of Fig. 3 a and c with Fig. 3 b and d shows that the surface density of silver nanoparticles was similar before and after electrolysis. It is interesting to note that similar SEM images were obtained after two/three electrolyses, whatever the electrolyte medium. The stability of the electrodes was confirmed by the comparable performances in terms of conversion of Alachlor ${ }^{\mathrm{TM}}$ obtained after two/three electrolyses.

\section{By-products analysis}

Deschloroalachlor has been previously identified as the main dechlorinated compound after cathodic reduction of Alachlor ${ }^{\mathrm{TM}}$ on Ag-modified Ni foams in the separated cell. ${ }^{51}$ Thus, the concentration of deschloroalachlor was followed by UPLC-MS/MS during the electrolysis. 
The conversion of Alachlor ${ }^{\mathrm{TM}}$ and the formation of deschloroalachlor on each Ag-modified Ni foam electrode were shown in Fig. 4. The highest yield of deschloroalachlor (69\%) was achieved on etched Ni-PVP-Ag electrode after $5 \mathrm{~h}$ of electrolysis with a yield of $\mathrm{Cl}^{-}$ions of $77 \%$ measured by ion chromatography. This dechlorination yield $(77 \%)$ was lower than the conversion yield of Alachlor ${ }^{\mathrm{TM}}(93 \%)$, meaning that by-products containing a chlorine atom were also formed during the electrolysis. Another interesting point is that, even if deschloroalachlor was the main dechlorinated by-product, the conversion to deschloroalachlor $(69 \%)$ was slightly lower than the yield of dechlorination, indicating the presence of some other dechlorinated by-products. This phenomenon was also observed with the other Agmodified electrodes as seen in table 3. The formation of two other by-products than deschloroalachlor could be observed by UPLC-MS/MS analysis with the presence of two peaks at $4.78\left(\mathrm{MH}^{+} 219.76\right)$ and $4.85 \mathrm{~min}\left(\mathrm{MH}^{+} 213.73\right)$, but we were not able to identify them. 

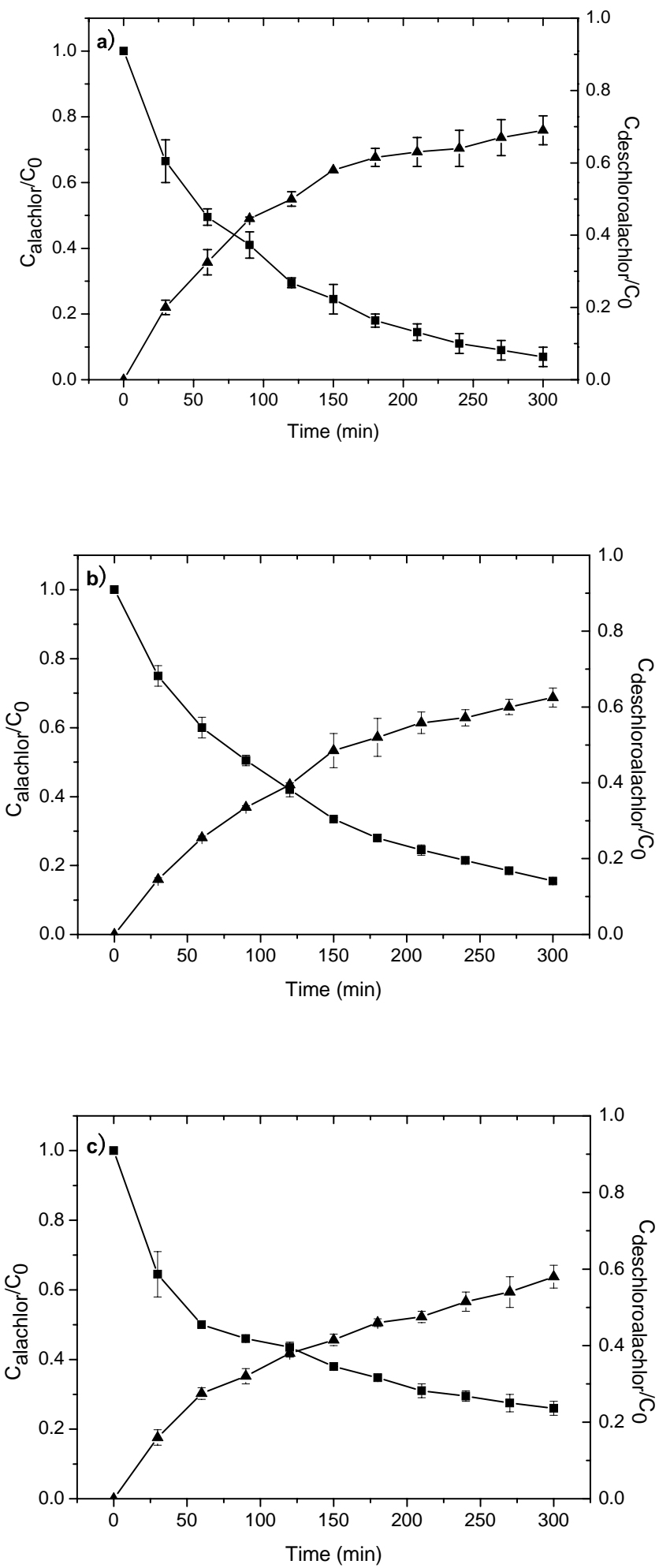

Figure 4. Evolution of the normalized concentration $\mathrm{C} / \mathrm{C}_{0}$ of $\operatorname{Alachlor}^{\mathrm{TM}}$ ( $\mathbf{\square}$ ) and deschloroalachlor $(\boldsymbol{\Delta})$ vs electrolysis time for the cathodic reduction of Alachlor ${ }^{\mathrm{TM}}\left(1.8 \times 10^{-4}\right.$ mol L-1; $50 \mathrm{ppm}$ ) performed at $-1.6 \mathrm{~V} / \mathrm{MSE}$ in $0.05 \mathrm{~mol} \mathrm{~L}^{-1} \mathrm{NaOH}$ at $3 \mathrm{~mL} \mathrm{~min}^{-1}$ on a) etched 
Ag-PVP-Ni, b) etched Ag-Ni, c) Ag-Ni. $\mathrm{C}_{\text {alachlor }}$ and $\mathrm{C}_{\text {deschloroalachlor are the concentrations of }}$ Alachlor $^{\mathrm{TM}}$ and deschloroalachlor at a given time and $\mathrm{C}_{0}$ the initial concentration of Alachlor ${ }^{\mathrm{TM}}$. Error bars are based on two reproducibility measurements.

Table 3. Reductive dechlorination at -1.6 V/MSE performed in $0.05 \mathrm{~mol} \mathrm{~L}-1$ NaOH solutions containing $50 \mathrm{ppm}$ Alachlor ${ }^{\mathrm{TM}}$ in a flow electrochemical cell with Ag-modified Ni foams (volume: $0.1335 \mathrm{~cm}^{3}$ ) for $5 \mathrm{~h}$.

\begin{tabular}{lll}
\hline Electrode & $\begin{array}{l}\text { Yield of deschloroalachlor } \\
\%\end{array}$ & Yield of $\mathrm{Cl}^{-\mathrm{a}, \mathrm{b} / \%}$ \\
\hline Ni foam & $16 \pm 2$ & $28 \pm 2$ \\
Etched Ni foam & $49 \pm 3$ & $61 \pm 1$ \\
Ag-Ni & $58 \pm 3$ & $69 \pm 3$ \\
Etched Ag-Ni & $63 \pm 2$ & $75 \pm 2$ \\
Etched Ag-PVP-Ni & $69 \pm 4$ & $77 \pm 2$ \\
\hline
\end{tabular}

${ }^{a}$ Uncertainties are based on two dechlorination experiments

${ }^{\mathrm{b}}$ measured by ion chromatography

\section{Biodegradability}

TOC measurements were performed on Alachlor ${ }^{\mathrm{TM}}$ solutions before and after electrolysis (Table 4). The TOC value of Alachlor ${ }^{\mathrm{TM}}$ before electrolysis was found to be $36.8 \mathrm{mg} \mathrm{L}^{-1}$, that was close to the values measured after electrolysis. This result indicated the expected poor mineralization of Alachlor ${ }^{\mathrm{TM}}$ during its electrochemical reduction since silver is known to give selective catalytic reduction of $\mathrm{C}-\mathrm{Cl}$ bonds $^{28,29,32,33}$ and pointed out the necessity to couple the electrolysis with a biological process, owing to the significant organic carbon available for microorganisms' growth. The slight decrease of the TOC value also confirms the presence of other by-products than deschloroalachlor, for which an increase of TOC would be expected. These by-products probably contain less carbon atoms than Alachlor ${ }^{\mathrm{TM}}$ since a lower value of TOC was obtained. $\mathrm{COD}$ and $\mathrm{BOD}_{5}$ were also measured to check the biodegradability of the solutions. The biodegradability of a compound can be estimated through the $\mathrm{BOD}_{5}$ on $\mathrm{COD}$ ratio and an effluent is considered as readily biodegradable if the value is beyond $0.4 .^{55,56}$ We have previously observed that a $50 \mathrm{ppm}$ solution of Alachlor ${ }^{\mathrm{TM}}$ $\left(1.8 \times 10^{-4} \mathrm{~mol} \mathrm{~L}^{-1}\right)$ was not biodegradable with a measured BOD 5 value lower than $2 \mathrm{mg} \mathrm{\textrm {L } ^ { - }}$ ${ }^{1} .19$ As seen in Table 4, the biodegradability remained low after electrolysis with all Agmodified electrodes, not only when the conversion of Alachlor ${ }^{\mathrm{TM}}$ was relatively low (Ag-Ni and etched Ag-Ni electrodes), but even with the etched Ag-PVP-Ni electrode, although up to 93\%, Alachlor ${ }^{\mathrm{TM}}$ was converted. The presence of deschloroalachlor that has previously shown biorecalcitrance $\left(\mathrm{BOD}_{5}<2 \mathrm{mg} \mathrm{L}^{-1}\right.$ for a solution of $50 \mathrm{ppm}$ of deschloroalachlor ${ }^{19}$ ) seems to 
prevent the increase of the $\mathrm{BOD}_{5}$ of the solution. This recalcitrance could be due to the presence of other functional groups in the structure of the formed by-products that would prevent their biodegradability. Indeed, the biorecalcitrance of the acetanilide ${ }^{57-59}$ and methoxyl ${ }^{60,61}$ groups has already been mentioned and a link between the biorecalcitrance of chloroacetanilide herbicides and the length of the alkoxymethyl substituents on the amide nitrogen has been observed. ${ }^{62}$ The authors explained it by a steric hindrance that would prevent the enzyme-substrate interaction.

These results shows that even if chlorine atoms are known to increase the biorecalcitrance of a molecule, the reductive treatment of Alachlor ${ }^{\mathrm{TM}}$ on etched Ag-PVP-Ni electrode did not lead to an easily biodegradable effluent. However, since these biodegradability measurements were only run over 5 days as it is usually performed in wastewater treatment plant with mainly household effluents, additional studies would be necessary to test the long-term biodegradability of Alachlor ${ }^{\mathrm{TM}}$ solutions.

Table 4. $\mathrm{COD}$, $\mathrm{TOC}$ and $\mathrm{BOD}_{5}$ determination of $50 \mathrm{ppm}$ Alachlor ${ }^{\mathrm{TM}}$ after reductive

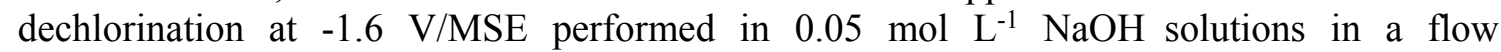
electrochemical cell with Ag-modified Ni foams (volume: $0.1335 \mathrm{~cm}^{3}$ ) for $5 \mathrm{~h}$.

\begin{tabular}{|c|c|c|c|c|}
\hline Electrode & $\begin{array}{l}\text { TOC (mg L- } \\
\text { 1) }\end{array}$ & $\begin{array}{l}\mathrm{COD}\left(\mathrm{mg} \mathrm{O}_{2} \mathrm{~L}^{-1}\right) \\
\mathrm{a}\end{array}$ & $\begin{array}{l}\mathrm{BOD}_{5}\left(\mathrm{mg} \mathrm{O}_{2} \mathrm{~L}^{-1}\right) \\
\end{array}$ & $\mathrm{BOD}_{5} / \mathrm{COD}$ \\
\hline $\mathrm{Ni}$ foam & 33.4 & $127 \pm 4$ & $-b$ & - \\
\hline Etched Ni foam & 33.6 & $114 \pm 0.5$ & $-b$ & - \\
\hline $\mathrm{Ag}-\mathrm{Ni}$ & 33.9 & $108 \pm 1.5$ & $<2$ & $<0.018$ \\
\hline Etched Ag-Ni & 31.4 & $100 \pm 4$ & $<2$ & $<0.02$ \\
\hline $\begin{array}{l}\text { Etched Ag-PVP- } \\
\mathrm{Ni}\end{array}$ & 30.9 & $90 \pm 3$ & $<2$ & $<0.022$ \\
\hline
\end{tabular}

${ }^{\mathrm{a}}$ Uncertainties are based on two dechlorination experiments

${ }^{b}$ Not measured

\section{CONCLUSIONS}

The reductive dechlorination of a chlorinated phytosanitary compound, Alachlor ${ }^{\mathrm{TM}}$, which is essential for long-term remediation of groundwater and surface water, has been achieved in this work in electrolytic conditions (electrolyte medium, flow electrochemical cell) that are adaptable in a large-scale treatment process. The electrochemical reduction was performed on Ag-modified Ni foams in a flow electrochemical cell in different electrolytes. Analysis of the 
electrolyzed solution with etched Ag-PVP-Ni in alkaline electrolyte showed 93\% conversion yield of the target pollutant and $77 \%$ dechlorination, underlining the high catalytic activity of the etched Ag-PVP-Ni electrode. The main dechlorinated by-product was deschloroalachlor, the dehalogenated form of Alachlor ${ }^{\mathrm{TM}}$, with a yield of $69 \%$. However, $\mathrm{BOD}_{5}$ measurements highlighted that this dechlorination step did not lead to an easily biodegradable solution, preventing the direct combination with a classical biological treatment using activated sludge. A longer biological treatment or a more efficient one using either acclimated sludge or specific bacteria would be necessary for a total mineralization of chloroacetanilide herbicides.

\section{ACKNOWLEDGMENTS}

Wenyan He and Yaoyin Lou thank the China Scholarship Council for a Ph.D grant.

\section{REFERENCES}

1 Amalric L, Baran N, Coureau C, Maingot L, Buron F, Routier S. Analytical developments for 47 pesticides: first identification of neutral chloroacetanilide derivatives in French groundwater. Int J Environ Anal Chem 93:1660-75 (2013).

2 Fernandez-Gomez C, Lopez-Lopez JA, Matamoros V, Diez S, Garcia-Vargas M, Moreno C. Atmospheric influence on the distribution of organic pollutants in the Guadalquivir River estuary, SW Spain. Environ Monit Assess 185:3209-18 (2013).

3 Postle JK, Rheineck BD, Allen PE, Baldock JO, Cook CJ, Zogbaum R, et al. Chloroacetanilide Herbicide Metabolites in Wisconsin Groundwater: 2001 Survey Results. Environ Sci Technol 38:5339-43 (2004).

4 Roubeix V, Fauvelle V, Tison-Rosebery J, Mazzella N, Coste M, Delmas F. Assessing the impact of chloroacetanilide herbicides and their metabolites on periphyton in the Leyre 
River (SW France) via short term growth inhibition tests on autochthonous diatoms. $J$ Environ Monit 14:1655-63 (2012).

5 Liu W-P, Fang Z, Liu H-J, Yang W-C. Adsorption of chloroacetanilide herbicides on soil and its components. III. Influence of clay acidity, humic acid coating and herbicide structure on acetanilide herbicide adsorption on homoionic clays. J Environ Sci (China) 14:173-80 (2002).

6 Liu W-P, Liu H-J, Zheng W, Lu J-H. Adsorption of chloroacetanilide herbicides on soil (I) structural influence of chloroacetanilide herbicide for their adsorption on soils and its components. J Environ Sci (China) 13:37-45 (2001).

7 Saha S, Dutta D, Karmakar R, Ray DP. Structure-toxicity relationship of chloroacetanilide herbicides: Relative impact on soil microorganisms. Environ Toxicol Pharmacol 34:307-14 (2012).

8 Tilak KS, Raju PW, Butchiram MS. Effects of alachlor on biochemical parameters of the freshwater fish, Channa punctatus (Bloch). J Environ Biol 30:421-6 (2009).

9 Dearfield KL, McCarroll NE, Protzel A, Stack HF, Jackson MA, Waters MD. A survey of EPA/OPP and open literature on selected pesticide chemicals. II. Mutagenicity and carcinogenicity of selected chloroacetanilides and related compounds. Mutat Res, Genet Toxicol Environ Mutagen 443:183-221 (1999).

10 Genter MB, Breckenridge C. Chloroacetanilide-induced nasal carcinogenesis in rats. Nose Viral Cancer:427-34 (2010).

11 Qin Y, Song F, Ai Z, Zhang P, Zhang L. Protocatechuic Acid Promoted Alachlor Degradation in Fe(III)/H2O2 Fenton System. Environ Sci Technol 49:7948-56 (2015).

12 Pipi ARF, De Andrade AR, Brillas E, Sires I. Total removal of alachlor from water by electrochemical processes. Sep Purif Technol 132:674-83 (2014). 
13 Choi D, Lee O-M, Yu S, Jeong S-W. Gamma radiolysis of alachlor aqueous solutions in the presence of hydrogen peroxide. J Hazard Mater 184:308-12 (2010).

14 Eykholt GR, Davenport DT. Dechlorination of the Chloroacetanilide Herbicides Alachlor and Metolachlor by Iron Metal. Environ Sci Technol 32:1482-7 (1998).

15 Satapanajaru T, Shea PJ, Comfort SD, Roh Y. Green Rust and Iron Oxide Formation Influences Metolachlor Dechlorination during Zerovalent Iron Treatment. Environ Sci Technol 37:5219-27 (2003).

16 Bian H, Chen J, Cai X, Liu P, Wang YS, Huang L, et al. Dechlorination of chloroacetanilide herbicides by plant growth regulator sodium bisulfite. Water Res 43:356674 (2009).

17 Calvo L, Gilarranz MA, Casas JA, Mohedano AF, Rodriguez JJ. Hydrodechlorination of alachlor in water using $\mathrm{Pd}, \mathrm{Ni}$ and $\mathrm{Cu}$ catalysts supported on activated carbon. Appl Catal B-Environ 78:259-66 (2008).

18 He WY, Fontmorin J-M, Hapiot P, Soutrel I, Floner D, Fourcade F, et al. A New Bipyridyl Cobalt Complex for Reductive Dechlorination of Pesticides. Electrochim Acta 207:313-20 (2016).

19 He WY, Fontmorin J-M, Soutrel I, Floner D, Fourcade F, Amrane A, et al. Reductive Dechlorination of a Chloroacetanilide Herbicide in Water by a Co Complex-Supported Catalyst. J Hazard Mater 432:8-14 (2017).

20 Okey RW, Stensel HD. A QSAR-based biodegradability model-A QSBR. Water Res 30:2206-14 (1996).

21 Martin ET, McGuire CM, Mubarak MS, Peters DG. Electroreductive Remediation of Halogenated Environmental Pollutants. Chem Rev 116:15198-234 (2016). 
22 Romanczyk PP, Rotko G, Kurek SS. Dissociative electron transfer in polychlorinated aromatics. Reduction potentials from convolution analysis and quantum chemical calculations. Phys Chem Chem Phys 18:22573-82 (2016).

23 Peters DG. Halogenated organic compounds. Org Electrochem (4th Ed):341-77 (2001).

24 Peters DG, McGuire CM, Pasciak EM, Peverly AA, Strawsine LM, Wagoner ER, et al. Electrochemical dehalogenation of organic pollutants. J Mex Chem Soc 58:287-302 (2014).

25 Fontmorin JM, He WY, Floner D, Fourcade F, Amrane A, Geneste F. Reductive dehalogenation of 1,3-dichloropropane by a [Ni(tetramethylcyclam)] $\mathrm{Br}_{2}-\mathrm{Nafion}$ modified electrode. Electrochim Acta 137:511-7 (2014).

26 Huang Y-F, Wu D-Y, Wang A, Ren B, Rondinini S, Tian Z-Q, et al. Bridging the gap between electrochemical and organometallic activation: benzyl chloride reduction at silver cathodes. J Am Chem Soc 132:17199-210 (2010).

$27 \mathrm{Xu} \mathrm{Y}$, Zhu Y, Zhao F, Ma C-a. Electrocatalytic reductive dehalogenation of polyhalogenated phenols in aqueous solution on Ag electrodes. Appl Catal, A 324:83-6 (2007).

28 Rondinini S, Vertova A. Electrocatalysis on silver and silver alloys for dichloromethane and trichloromethane dehalogenation. Electrochim Acta 49:4035-46 (2004).

29 Durante C, Isse AA, Gennaro A. Electrocatalytic dechlorination of polychloroethylenes at silver cathode. J Appl Electrochem 43:227-35 (2013).

$30 \mathrm{Xu} \mathrm{YH}$, Zhang $\mathrm{H}$, Chu CP, Ma CA. Dechlorination of chloroacetic acids by electrocatalytic reduction using activated silver electrodes in aqueous solutions of different pH. J Electroanal Chem 664:39-45 (2012). 
31 Peverly AA, Karty JA, Peters DG. Electrochemical reduction of (1R,2r,3S,4R,5r,6S)hexachlorocyclohexane (Lindane) at silver cathodes in organic and aqueous-organic media. $J$ Electroanal Chem 692:66-71 (2013).

32 Durante C, Isse AA, Sandona G, Gennaro A. Electrochemical hydrodehalogenation of polychloromethanes at silver and carbon electrodes. Appl Catal, B 88:479-89 (2009).

33 Scialdone O, Guarisco C, Galia A, Herbois R. Electroreduction of aliphatic chlorides at silver cathodes in water. J Electroanal Chem 641:14-22 (2010).

34 Ma CA, Li MC, Liu YN, Xu YH. In situ FTIR studies on the electrochemical hydrodechlorination of 3,4,5,6-tetrachloropicolinic acid on Ag cathode. Electrochim Acta 55:3171-4 (2010).

35 Xu Y, Ding X, Ma H, Chu Y, Ma C. Selective hydrodechlorination of 3,5,6trichloropicolinic acid at an activated silver cathode: Synthesis of 3,5-dichloropicolinic acid. Electrochim Acta 151:284-8 (2015).

36 McGuire CM, Peters DG. Electrochemical dechlorination of 4,4'-(2,2,2trichloroethane-1,1-diyl)bis(chlorobenzene) (DDT) at silver cathodes. Electrochim Acta 137:423-30 (2014).

37 Wang Z, Huang W, Peng Pa, Fennell DE. Rapid dechlorination of 1,2,3,4-TCDD by Ag/Fe bimetallic particles. Chem Eng J 273:465-71 (2015).

38 Luo S, Yang S-G, Wang X-D, Sun C. Reductive degradation of tetrabromobisphenol A over iron-silver bimetallic nanoparticles under ultrasound radiation. Chemosphere 79:672-8 (2010).

39 Ma C-a, Ma H, Xu Y-h, Chu Y-q, Zhao F-m. The roughened silver-palladium cathode for electrocatalytic reductive dechlorination of 2,4-dichlorophenoxyacetic acid. Electrochem Commun 11:2133-6 (2009). 
$40 \mathrm{Xu} \mathrm{YH}$, Cai QQ, Ma HX, He Y, Zhang H, Ma CA. Optimisation of electrocatalytic dechlorination of 2,4-dichlorophenoxyacetic acid on a roughened silver-palladium cathode. Electrochim Acta 96:90-6 (2013).

41 O'Loughlin EJ, Kemner KM, Burris DR. Effects of AgI, AuIII, and CuII on the Reductive Dechlorination of Carbon Tetrachloride by Green Rust. Environ Sci Technol 37:2905-12 (2003).

42 Xu Y, Zhang W-x. Subcolloidal Fe/Ag Particles for Reductive Dehalogenation of Chlorinated Benzenes. Ind Eng Chem Res 39:2238-44 (2000).

43 Patel U, Suresh S. Dechlorination of chlorophenols by magnesium-silver bimetallic system. J Colloid Interface Sci 299:249-59 (2006).

44 Ghauch A, Tuqan A. Reductive destruction and decontamination of aqueous solutions of chlorinated antimicrobial agent using bimetallic systems. J Hazard Mater 164:665-74 (2009).

45 He Z, Sun J, Wei J, Wang Q, Huang C, Chen J, et al. Effect of silver or copper middle layer on the performance of palladium modified nickel foam electrodes in the 2chlorobiphenyl dechlorination. J Hazard Mater 250-251:181-9 (2013).

46 Hu G, Lai S, Ye C, Li A, Liu J, Lai X, et al. A high-performance and well-dispersed Ag-Pd/UCNTs catalyst for aqueous-phase dechlorination of chlorobenzene. Mater Lett 93:278-81 (2013).

47 He Z, Zhan L, Wang Q, Song S, Chen J, Zhu K, et al. Increasing the activity and stability of chemi-deposited palladium catalysts on nickel foam substrate by electrochemical deposition of a middle coating of silver. Sep Purif Technol 80:526-32 (2011).

48 Lugaresi O, Encontre H, Locatelli C, Minguzzi A, Vertova A, Rondinini S, et al. Gasphase volatile organic chloride electroreduction: A versatile experimental setup for electrolytic dechlorination and voltammetric analysis. Electrochem Commun 44:63-5 (2014). 
Liu B, Ding C, Xiao B, Cui L, Wang M. Electrocatalytic dechlorination of chloroacetic acids on silver nanodendrites electrode. Mater Sci Eng, C 37:108-12 (2014).

50 Minguzzi A, Lugaresi O, Aricci G, Rondinini S, Vertova A. Silver nanoparticles for hydrodehalogenation reduction: Evidence of a synergistic effect between catalyst and support. Electrochem Commun 22:25-8 (2012).

51 Verlato E, He WY, Amrane A, Barison S, Floner D, Fourcade F, et al. Preparation of Ag-modified Ni foams by galvanic displacement and their use as cathodes for the reductive dechlorination of herbicides. Chemelectrochem 3:2084-92 (2016).

52 Slistan-Grijalva A, Herrera-Urbina R, Rivas-Silva JF, Avalos-Borja M, CastillonBarraza FF, Posada-Amarillas A. Synthesis of silver nanoparticles in a polyvinylpyrrolidone (PVP) paste, and their optical properties in a film and in ethylene glycol. Mater Res Bull 43:90-6 (2008).

53 Koczkur KM, Mourdikoudis S, Polavarapu L, Skrabalak SE. Polyvinylpyrrolidone (PVP) in nanoparticle synthesis. Dalton Trans 44:17883-905 (2015).

54 Wang H, Qiao X, Chen J, Wang X, Ding S. Mechanisms of PVP in the preparation of silver nanoparticles. Mater Chem Phys 94:449-53 (2005).

55 Sarria V, Parra S, Adler N, Peringer P, Benitez N, Pulgarin C. Recent developments in the coupling of photoassisted and aerobic biological processes for the treatment of biorecalcitrant compounds. Catal Today 76:301-15 (2002).

56 Pulgarin C, Invernizzi M, Parra S, Sarria V, Polania R, Peringer P. Strategy for the coupling of photochemical and biological flow reactors useful in mineralization of biorecalcitrant industrial pollutants. Catal Today 62:131 (2000).

57 Stamper DM, Tuovinen OH. Biodegradation of the acetanilide herbicides alachlor, metolachlor, and propachlor. Crit Rev Microbiol 24:1-22 (1998). 
58 Slaba M, Szewczyk R, Piatek MA, Dlugonski J. Alachlor oxidation by filamentous fungus Paecilomyces marquandii. J Hazard Mater 261:443-50 (2013).

59 Zitko V. Prediction of biodegradability of organic chemicals by an artificial neural network. Chemosphere 23:305-12 (1991).

60 Bertelkamp C, Verliefde ARD, Reynisson J, Singhal N, Cabo AJ, de Jonge M, et al. A predictive multi-linear regression model for organic micropollutants, based on a laboratoryscale column study simulating the river bank filtration process. J Hazard Mater 304:502-11 (2016).

61 Martin A. Biodegradation and Bioremediation, second edition. Press A, editor. San diego: Harcourt Brace and Conpany; 1999.

62 Zhang J, Zheng J-W, Liang B, Wang C-H, Cai S, Ni Y-Y, et al. Biodegradation of Chloroacetamide Herbicides by Paracoccus sp. FLY-8 in Vitro. J Agric Food Chem 59:461421 (2011). 